\title{
Crimes and Punishments, Part II: Noachide Law, Brother-Sister Intercourse, and the Case of Murder
}

\author{
Devora Steinmetz \\ Jewish Theological Seminary
}

I

n Part I of this study, ${ }^{1}$ I proposed that the mode of execution that rabbinic sources assign to violations of sinaitic law be seen as a reflection of rabbinic jurisprudence. I analysed the nature of execution by cheneq (strangulation) as described in rabbinic sources, and I argued that this mita (mode of execution), which is designated as the default mita for violations of sinaitic law for which the Torah does not designate the mode of execution, reflects the rabbinic understanding of sinaitic law and its violation.

Specifically, I suggested that cheneq is the court's realisation of expiration, the human being's relinquishing of the life-force with which God inspired the human being. This sanction, I argued, matches the rabbinic conception of sinaitic law as based wholly in divine command. Sanctionable violation of sinaitic law is a conscious and wilful violation of God's command, and this results in the necessity of the violator giving up the God-given breath of life. Cheneq is the judicial implementation of the process that is necessitated by the criminal's violation of God's command.

In the second part of this study, I will test the core idea presented in Part I-that punishment in rabbinic sources can be seen as a reflection of jurisprudence-by looking at alternative bodies of law envisioned in rabbinic sources (actually, at two versions of a single alternative body of lawnoachide law-described in the Bavli). ${ }^{2}$ I will argue that these two bodies of law represent alternative conceptions of law and that these conceptions are reflected in the sanction that is assigned to each of these bodies of law. Both of these conceptions of law, while distinct from each other, are radically different from what I have described as the rabbinic conception of sinaitic law,

\footnotetext{
1 'Crimes and Punishments, Part I: Mitot Beit Din as a Reflection of Rabbinic Jurisprudence', JJS 55 (2004), pp. 81-101.

2 It is, of course, debatable how much consistency (and what kinds of consistency) we should expect in rabbinic sources. In this case, one could accept that the punishment of cheneq reflects the rabbinic conception of sinaitic law without necessarily expecting that punishments assigned in rabbinic sources to alternative bodies of law reflect the rabbinic conception of those bodies of law. Nevertheless, the possibility that a jurisprudential analysis of punishment can be extended beyond the case of cheneq bears investigation. And it should be noted that the main rabbinic sources that will be discussed in relation to the three main topics addressed below-noachide law, brother-sister intercourse, and murder - are from bSanhedrin, as are the main sources discussed in 'Crimes and Punishments, Part I' in relation to mitot beit din and the rabbinic conception of sinaitic law. Nevertheless, it could still be argued that one should not expect the kind of consistency even within a single tractate that I am looking for here. For the degree to which my argument is about the Bavli or about rabbinic sources in general, see the introduction to 'Crimes and Punishments, Part I'.
} 
and I will highlight the distinction between these different conceptions of law by looking at rabbinic sources relating to brother-sister intercourse - an act that is a paradigmatic violation of sinaitic law but which is not criminal ${ }^{3}$ in noachide law.

Finally, I will return to the focus on punishment as a reflection of the nature of law but look, this time, not at a system of law but at a single crime and its punishment. I will look at the crime of murder, which is assigned the exceptional mita of hereg (death by sword) in rabbinic sources. I will argue that murder is seen as different in kind from other crimes within sinaitic law, and that the nature of this act as understood in rabbinic sources is reflected in the sanction that rabbinic sources assign to murder. Thus, I will suggest, my argument about punishments as a reflection of jurisprudence in rabbinic sources extends beyond the case of cheneq as the default mita for violations of sinaitic law: it applies to alternative systems of law envisioned in rabbinic texts, and it can apply to a single law seen to be exceptional within a body of law.

\section{Noachide Law}

First, let us look at conceptions of sheva mitzvot benei noach - the seven noachide laws. ${ }^{4}$ While the idea of noachide laws appears often in rabbinic texts, within the Bavli there are, in fact, two different traditions about the list of seven laws, the sources for these laws, and the sanction for violation of the laws. ${ }^{5}$ I will suggest that the two traditions about the content and source of

${ }^{3}$ See below for a qualification of this generalisation.

${ }^{4}$ For a review of some of the extensive literature on noachide law, see S. Stone, 'Sinaitic and Noahide Law: Legal Pluralism in Jewish Law', Cardozo Law Review 12 (1991), 1157-1214. See D. Novak, The Image of the Non-Jew in Judaism (New York, 1983) for a survey of understandings of noachide law and of the specific laws.

5 bSan 56a-57b. The idea of noachide law comes up in many places in rabbinic sources; see Bereishit Rabba 16:6 and the note on parallels in the Theodor-Albeck edition, pp. 149-50. Generally, if the mitzvot are said to have been commanded to Adam, then the initial number of mitzvot is said to be six, the seventh — eating the limb of a living animal-having been added only when God permitted Noach and his sons to eat meat. It is striking that, in the beginning of the sugya in the Bavli, the mitzvot are listed as seven and said to have been commanded to Noach (bSan 56a), but this list of seven noachide laws is then linked to God's command to Adam (56b). The Bavli also differs from most other sources in that, according to the first interpretation presented, dinin is the first in the list of mitzvot, derived from the first word of the biblical verse containing God's command-vayetzav. (In tAvoda Zara 9:7, dinin is listed first; this source does not link the laws to Gen. 2:16. In a passage relating to the laws taught at Mara in Seder Olam, chapter 5, dinin is listed first and linked to the word vayetzav in Gen. 2:16; this passage also juxtaposes the notion of seven noachide laws with God's command to Adam.) See below, n. 9. Several rabbinic sources, including the Bavli, include other opinions about possible additional miztvot, but only the Bavli includes two separate opinions about the items that constitute a set of seven mitzvot, the second of which is attributed to Tanna deVei Menashe. For ease of reference, I will refer to each of the clusters of positions that the Bavli develops - each cluster consisting of a list of laws, the source of the laws, and the punishment for violation of law-as the position of the Rabbis or of Tanna deVei Menashe. In fact, the clustering of these positions is a construct of the Bavli, as might be true of the notion that there is a second position about a set of seven mitzvot that of Tanna deVei Menashe - at all. The discussion of these two positions, then, should be understood to be a discussion of two presentations of noachide law as developed in the Bavli. 
the sheva mitzvot reflect two different conceptions of noachide law, unique to the Bavli, and that these two conceptions are reflected as well in the different mitot mandated in relation to the two traditions.

The first, standard position (which I will refer to as the opinion of the Rabbis) includes the following seven laws: the command to establish a judicial system and prohibitions against blasphemy, idolatry, sexual misconduct, murder, theft, and eating the limb of a living animal. The source of all of these laws is said to be Gen. 2:16 - 'The Lord God commanded the human being saying: From any tree of the garden you may surely eat ${ }^{\prime}{ }^{6}$ - each law being suggested by one or more words interpreted either independently or in reference to another verse.

The second position, attributed by the Bavli to Tanna deVei Menashe, omits two items from the above list - the command to establish a judicial system and the prohibition against blasphemy - and replaces them with two prohibitions: castration and cross-breeding. ${ }^{7}$ The gemara sees this second list of seven laws as deriving from sources other than Gen. 2:16, different items on the list deriving from different sources. For example, idolatry and sexual offences derive from Gen. 6:11 - 'The earth was destroyed ${ }^{8}$ before the Lord'along with other verses that are cited to link the word 'destroyed' with these two sins.

Paying attention, first, to the biblical sources associated with the lists of laws in the Bavli and then to the items included in each of the lists, one outstanding difference is immediately apparent. The Rabbis' list is associated with a verse that describes a command-'The Lord God commanded the human being ...' (Gen. 2:16). And the very first item in the Rabbis' list is dinin - the requirement to set up a judicial system. According to the first of two opinions cited in the Bavli as to how the seven items are linked to the words of the verse, in fact, the requirement of dinin is derived from the word vayetzav - 'commanded'. ${ }^{9}$ The Rabbis' list of noachide laws, then, is

\footnotetext{
${ }^{6}$ As noted in the preceding note, it is unique to the Bavli that the notion of seven laws commanded to noachides is linked to this verse in which God commands Adam. The common reference to noachide laws (rather than, say, adamic laws), and to benei noach (rather than benei adam) in reference to culpability under those laws, may derive from the fact that, in the Torah, it is only after the Flood that humankind is first given general injunctions (as opposed to the very specific command given to Adam in Gen. 2:16-17), among which, depending on how one reads Gen. 9:6, one might see the mandate for human beings to institute a system of justice. (See my 'Vineyard, Farm, and Garden: The Drunkenness of Noah in the Context of Primeval History', Journal of Biblical Literature 113 (1994), 193-207, for a discussion of the shift in the nature of human responsibility and autonomy between the ante-diluvean and post-diluvean worlds.) If so, it is indeed curious that the notion of the origin of these laws is pushed back to the very beginnings of humankind.

7 As noted above, n. 5, other rabbinic sources mention these two laws as possible additions to the list of seven laws, among other possible additions - see, for example, Bereishit Rabba 34:8, and see below, n. 15. But the Bavli presents Tanna deVei Menashe's view alongside the Rabbis' view as representing an alternative system of seven laws, deriving from different sources, and with a different sanction.

8 The word vatishacheit might be less literally translated as 'was corrupted' or the like; I am using the translation 'was destroyed' in order to retain the link with other uses of $s h-c h-t$ in this passage, noted below.
}

9 Note that, in the Hebrew, the word 'commanded' appears as the first word in the verse. A 
grounded in legislation - vayetzav - and it requires a judicial system - dinin to implement the law. ${ }^{10}$

Tanna deVei Menashe's list, in contrast, is not associated with verses that describe commands; in fact, only one item on the list, eating the limb of a living animal, is derived from a verse that takes the form of an injunction (Gen. 9:4). ${ }^{11}$ Not only is this list dissociated from the vayetzav verse, ${ }^{12}$ it also does not include dinin. ${ }^{13}$ The first thing we note, then, is that this second list of mitzvot is neither grounded in legislation nor linked to a judicial system.

Moving on to look as what laws are included and the sources given for those laws, we can see what is the basis of law according to this second presentation of noachide law. Tanna deVei Menashe, omitting dinin and blasphemy, includes instead the prohibitions of castration and cross-breeding. These two acts are violations of the world as it was created: castration negating the capacity of reproduction and cross-breeding altering the categories of creatures and also, perhaps, yielding sterile progeny. ${ }^{14}$ The Bavli sees the source of these two prohibitions not in commands but in verses that stress the good of procreation and of sustaining the kinds of creatures that God created. Castration is derived from God's charge to Noach and his sons after the Flood: 'bring forth abundantly in the earth and multiply in it' (Gen. 9:7). And cross-breeding is derived from God's instructions to Noach to bring specimens of each animal kind into the ark: 'of birds according to their kinds' (Gen. 6:20). ${ }^{15}$ Both

second opinion derives dinin from elohim, which is the derivation that appears in Bereishit Rabba 16:6 and parallels (with the exception of Seder Olam; see n. 5, above), where the order of the laws is, correspondingly, different. These two derivations may reflect different conceptions of the basis, and perhaps of the content, of law; for one such interpretation, see Responsa of Rabbi Moses Isserles 10 and the discussion in N. Rakover, 'Jewish Law and the Noachide Obligation to Preserve Social Order', Cardozo Law Review 12 (1991), 1073-1136, and in Stone, 'Sinaitic', pp. $1173-74$.

${ }^{10}$ For a discussion of the meaning of dinin in rabbinic sources and the elaboration of this concept in later Jewish thought to include not only the establishment of a judicial system but also the mandate to develop systems of conventional law, see Stone, 'Sinaitic', pp. 1171-75.

11 A second item, murder, derives from a verse (Gen. 9:6) that can be read as a legal statement, though it does not take the form of a command not to murder; it speaks only of the penalty or consequence of murder.

12 tanna devei menashe... la darish vayetzav-bSan 56b.

13 The other item from the Rabbis' list omitted in Tanna deVei Menashe's list is blasphemybirkat hashem. Perhaps we ought to see blasphemy as linked to dinin - see the midrash that an unfavourable court decision is what led to the blasphemy described in Lev. 24:11 (Sifra on 24:10; ed. Weiss, 104b) and the two interpretations of 'elohim lo teqaleil' (Ex. 22:27) in Mekhilta deRabbi Yishmael, Kaspa 19, ed. Horovitz-Rabin, p. 317: that this is a statute prohibiting blasphemy, the punishment for which is stated in Lev. 24:16; or that this is a prohibition against cursing judges, interpreting elohim as in Ex. 22:8. On the other hand, blasphemy is listed among the five examples of reasonable laws in Sifra on Lev. 18:4 (86a) and bYoma 67b (see n. 36, below), in the absence of dinin; in the Sifra it comes right after idolatry (though in bYoma these two items are not proximate), and perhaps blasphemy should simply be seen as a fundamental religious prohibition alongside idolatry.

14 On cross-breeding as a violation of the order of creation, see Nachmanides' commentary on Lev. 19:19.

15 In Bereishit Rabba 34:8, castration and cross-breeding are similarly derived from 'by their families' in Gen. 8:19. (See also Bereishit Rabba 7 and yKil 1:6/27a for the link between crossbreeding and 'according to their kinds' in the creation story; see also bBavaQama 55a.) Crossbreeding is also mentioned in the Bavli as a possible addition to the Rabbis' list of noachide laws 
verses echo the language of the creation story ${ }^{16}$ and emphasise, along with many other verbal and thematic echoes, the re-establishment of the world after the Flood as a re-creation of the world. ${ }^{17}$

While most of the other items on the list, as already noted, also are not associated with verses that constitute commands, the source for idolatry and sexual misconduct is particularly telling: 'The earth was destroyed before the Lord ...' (Gen. 6:11). This passage, introducing the biblical account of the Flood, continues: 'The Lord saw the earth and, behold, it was destroyed, for all flesh had destroyed its way on the earth' (Gen. 6:12). ${ }^{18}$ It is only then that God informs Noach: 'The end of all flesh has come before me ... and, behold, I shall destroy them with the earth' (Gen. 6:13). The implication of this repeated use of the word 'destroy' in this biblical passage is that God, in bringing the Flood, is simply reifying the destruction that the world has already suffered through the destructive behaviour of its inhabitants. As the source that the Bavli gives for two of the prohibited acts on Tanna deVei Menashe's list, then, the phrase 'the earth was destroyed before the Lord' suggests that these acts - not unlike castration and cross-breeding, though perhaps in a less-literal sense - are forbidden in that they are destructive of the world as God the creator meant it to be.

It seems, then, that these two lists of noachide laws associated with these different biblical sources offer two very different conceptions of noachide law. The view that the Bavli attributes to Tanna deVei Menashe view seems similar to natural law in its classical sense. ${ }^{19}$ The world is created and operates according to certain principles; these principles are normative; the content of law is derivable from observation of the world as it is. ${ }^{20}$ Castration is unlawful because it violates the principle of reproduction inherent in the world as

(bSan 56a); see below.

16 Gen. 1:21-28.

17 For the Flood as an un-creation followed by a re-creation of the world, see Steinmetz, 'Vineyard' and the literature cited there.

18 It is from this verse that the gemara argues that 'destroyed' in the preceding verse connotes sexual misconduct.

19 Stone, 'Sinaitic', reviews some of the literature on noachide law and natural law and rejects the notion that noachide law is a form of natural law. Her analysis, though, is focused on the Rabbi's list of noachide laws, especially on dinin, and does not address Tanna deVei Menashe's position as an alternative conception of noachide law. For the debate on whether the notion of natural law exists within rabbinic thought, see the sources cited in Stone, pp. 1167-68, nn. 3637, and see especially M. Fox, 'Maimonides and Aquinas on Natural Law', Dine Israel 3 (1972), V-xxxvi (see the discussion below); A. Lichtenstein, 'Does Jewish Tradition Recognise an Ethic Independent of Halakha?', in M. Fox, ed., Modern Jewish Ethics: Theory and Practice (Ohio, 1975), 62-88; J. D. Bleich, 'Judaism and Natural Law', Jewish Law Annual 7 (1988), 6-42; D. Novak, 'Natural Law, Halakhah, and the Covenant', Jewish Law Annual 7 (1988), 43-67; and Rakover, 'Jewish Law'. My own concern here is not to determine whether either conception of noachide law is properly classified as 'natural law' (in one or another or its transformations); rather, I refer here to conceptions of natural law simply to help clarify my analysis of the two versions of noachide law.

20 For an introduction to different theories of natural law from ancient to contemporary times, see L. Weinreb, Natural Law and Justice (Cambridge, 1987); see ch. 1 for the classical version of natural law as it was developed within Stoic philosophy and articulated by Cicero. The providential, ontological, normative and epistemological elements of this conception of natural law are highlighted, as well, in Weinreb's summary of the classical approach on pp. 52-53. 
it was created and as it must operate; we can know that sexual offences are un-lawful because we observe that these acts cause destruction (un-creation) of the world. These acts are unlawful not because they are prohibited by a command, but because they violate the world order; we know that they are unlawful not based on a statute that forbids them, but because we can see how committing them brings destruction of the world as it is and ought to be.

The Rabbis' view seems closer to contemporary 'natural law' theories, which share little with the classical, ontological conception yet still are distinct from the positivist view that I have suggested characterises the rabbinic understanding of sinaitic law. The view of law that underlies this description of noachide law and its source seems to see law as emerging with the beginnings of human society. ${ }^{21}$ The content of law consists of basic prohibitions designed to ensure the functioning of human society, but these are laws not in the sense of normative principles within the natural order but in the sense of commands within human society. Though originating in command, this second conception is nevertheless different from a positivist conception in that, in the former, the content of the law is a constraint on the legitimacy of the law; a law's legitimacy does not derive exclusively from the process of legislation, as in positivist conceptions of law. ${ }^{22}$ Minimally, this means that law cannot violate dictates of morality; maximally, this means that the content of law is dictated by morality. In the case of the Rabbis' conception of noachide law, I am suggesting, while law is conceived of as legislated, the content of law is limited to that which is seen as necessary for social life, from a religious perspective of course, to function. ${ }^{23}$ Further, in that human society requires law, human beings must work to implement the law; ${ }^{24}$ the very first law is the commandment of dinin..$^{25}$

A detail in the extended sugya in the Bavli underscores the difference between the two conceptions of law that I am suggesting are reflected in the Bavli's two versions of noachide law. Cross-breeding, one of the laws in Tanna deVei Menashe's list, is also suggested in this sugya as a possible addition to

${ }^{21}$ See n. 6, above. Note that the very next verse after God's command in Gen. 2:16-17 has God saying: 'It is not good for the human being to be alone ....'

22 See B. S. Jackson, 'Secular Jurisprudence and the Philosophy of Jewish Law: A Commentary on Some Recent Literature', Jewish Law Annual 6 (1987), 3-44, especially section 5. While the content of law can be a constraint within positivist theories as well, that would be so only if such a constraint is build into the rules of legislation within a given system of law.

${ }^{23}$ For the post-talmudic notion that noachide law is to be expanded to meet the needs of society, see n. 10, above, and especially pp. 1174 and 1181-83 in Stone, 'Sinaitic'.

24 In a passage absent from standard editions of Mishne Tora, Maimonides emphasises the social aspect of noachide law. Maimonides says that, if a noachide saw another noachide violating a noachide law 'and did not judge him and kill him', then that person is himself to be killed (see Kapach edition, Hilkhot Melakhim 9:19, corresponding to 9:14 in the standard edition). The obligation to maintain adherence to the law and to punish violations of the law falls on every member of society. Maimonides uses this principle to explain why all of the inhabitants of Shekhem were deserving of death (Gen. 34). See Nachmanides' response in his comment on Gen. 34:13 for an alternative understanding of dinin and of the responsibility of individual noachides to respond to criminal acts.

25 See Stone, 'Sinaitic', p. 1165, and Novak, Image, pp. 386-90, for conceptions of noachide law in the writings of John Selden, Hugo Grotius and Hermann Cohen. 
the Rabbis' list of seven noachide laws. ${ }^{26}$ But, rather than giving as the source of this law the passage cited as the source for the inclusion of cross-breeding in Tanna deVei Menashe's list - 'of birds according to their kinds' (Gen. 6:20) the Bavli offers as the source for this addition to the Rabbis' list the phrase with which the prohibition of cross-breeding is introduced in Leviticus: 'you shall keep my statutes' (Lev. 19:19). ${ }^{27}$ The Bavli explains this to mean 'you shall keep the statutes that I have already legislated for you,' suggesting that this law was legislated in pre-rabbinic times. So the Bavli, which has already explained this law in reference to Tanna deVei Menashe's position as emerging from the way the world was recreated in the time of Noach, now explains this very same law, in reference to the Rabbis' position, as emerging from an act of legislation! ${ }^{28}$

The two versions of noachide law in the Bavli, which I have suggested reflect two different conceptions of the origin and nature of law, are assigned different forms of capital punishment. Tanna deVei Menashe is said to hold noachide laws to be punishable by cheneq, while the Rabbis hold them to be punishable by hereg. ${ }^{29}$ If, as I have suggested, Tanna deVei Menashe's prohibitions are of acts that violate the principles of creation, that destroy the world as it is meant to be, then death by cheneq is indeed fitting. Cheneq, I argued in Part I of this study, is the undoing of the process by which the human being comes to life. In cheneq, the life-breath with which the person is brought to life is taken away - the violator expires, reversing the inspiration with which the human being is created and each person is brought to life. If we see noachide crimes as acts that un-create the world, then it is natural that they result in the un-creation of human life.

In fact, cheneq is the cause of death of the human beings (and other creatures) killed in the flood; ${ }^{30}$ as we have seen, the flood represents God's de-

\footnotetext{
26 bSan $56 b$.

27 bSan 60a.

28 Interestingly, Rashi and Tosafot take a similar approach when explaining the Bavli's derivation of idolatry and sexual misconduct, as they appear in Tanna deVei Menashe's list, from the phrase 'the earth was destroyed before the Lord'. Rashi comments (bSan 57a, s.v. vatishacheit ha'aretz): 'From the fact that he was punished for them, we can infer that he was commanded concerning them.' Compare Tosafot (s.v. dikhtiv vatishacheit): 'And he would not have punished without having prohibited (hizhir).' Both Rashi and Tosafot interpret the verse describing the destruction of the world as a punishment that, of necessity, implies that, prior to that, God must have articulated a prohibition to humankind. Rashi and Tosafot, then, are interpreting the gemara's explanation of Tanna deVei Menashe's position in a way that makes it consistent with the Rabbis' position - that God has legislated for humanity and that people are punished when they violate those commands. (See bSan 56b and tAvoda Zara 9:7, where this argument is made in support of possible additions to the standard list of seven mitzvot.) As I have suggested, though, the simple meaning of the Bavli is that human beings have engaged in destructive acts and that destruction naturally comes upon them in consequence - and that these acts are forbidden not in that they have been prohibited by God's command but in that they are destructive of God's world.

29 Tanna deVei Menashe-bSan 57b, 71b; the Rabbis—bSan 56a.

${ }^{30}$ For drowning as cheneq, see bSan 37b and the sources cited in Y. Lorberbaum, Imago Dei: Rabbinic Literature, Maimonides and Nachmanides (in Hebrew), PhD dissertation, Hebrew University (Jerusalem, 1997), p. 121, n. 147; see also 'Crimes and Punishments, Part I', n. 53. V. Aptowitzer, 'Observations of the Criminal Law of the Jews', JQR n.s. 15 (1924-1925), 55-118,
} 
struction of God's creation attendant upon the destruction that the world has already endured through the actions of its inhabitants (Gen. 6:11-13). It is from elements of this destruction and the re-creation of the world in its aftermath that the Bavli derives the noachide laws according to the position of Tanna deVei Menashe. Thus, the sanction of cheneq for violation of noachide law is, in a sense, an uncreation by 'flood' of the person who has engaged in world-destroying acts.

In contrast, violation of noachide law according to the Rabbis incurs the penalty of hereg. I have suggested that the noachide laws of the Rabbis have their root in the establishment of human society - they are the fundamental laws that allow for a moral society that can govern itself. Hereg is 'killing'-it is the way one human being kills another, ${ }^{31}$ not, like cheneq, an approximation of the way people die. A conception of law that has as its basis legislation to human society and that incorporates as an essential element the establishment of a human system of justice fits well with the notion of execution by hereg. ${ }^{32}$ The person who violates the legal underpinnings of human society deserves to be killed by fellow human beings. ${ }^{33}$

correlates the two traditions about how Qayin, the first murderer, was killed - in the flood, at the hand of God, or by an arrow, at human hands - with the two opinions about how noachides are killed for violating the law-cheneq or hereg.

31 Descriptions of human slaying of other human beings are characterised by uses of $h-r-g$, the motif of 'spilling blood', and mention of weapons that pierce the body, such as sword and arrows. For just a few examples, see Gen. 4:14 (Qayin's fear that he will be killed for having spilled his brother's blood - see Gen. 4:10); Gen. 4:23 (Lemekh's boast of having killed/or being capable of killing someone who has wounded him/or by means of inflicting a wound); Gen. 27:41-42 (Esav's plan to kill his brother - see Gen. 27:40 for his living by his sword); Gen. 34:25-26 (the killing of the inhabitants of Shekhem and its leaders 'by sword'-see also Gen. 48:22); Gen. 37:20, 22 (the plan to kill Yosef and Re'uven's plea not to spill blood). Contrast the death - mita — caused by God in Gen. 38:7, 10 (the death of Er and Onan), the passage cited by Rashi to explain the term 'death by the hand of heaven' in Rabbi's explanation of the source of cheneq (see Rashi on bSan 52b, s.v. ne'emar mita biydei shamayim, and the discussion in 'Crimes and Punishments, Part I', n. 51).

32 Note that hereg is also the mode of execution that rabbinic sources assign to secular government, Jewish and non-Jewish (see the sources in nn. 88 and 89, below). See the discussion below of hereg as the punishment for murder in the sinaitic system.

33 While the Bavli gives as the source for Tanna deVei Menashe's position that a violation of noachide law is punishable by cheneq a reading of Gen. 9:6- ba'adam damo yishafeikh $=$ an internal spilling of blood (bSan 57b) - the source for the Rabbis' position that a noachide is executed by hereg is less clear. It would be reasonable to assume that the source is also Gen. 9:6 - ba'adam damo yishafeikh = spilling of blood by a human being - and this is the source given by Rashi (bSan 56a, s.v. eina ela sayif). According to one interpretation of qatlayhu hu deqamegali (bSan 57a), this derivation is, in fact, stated in the gemara, though these words can alternatively be read as saying that Gen. 9:6 mandates execution for violations of noachide law, rather than that it specifies the form of execution (see Rashi on bSan 57a, s.v. qatlayhu qa megali, and Yad Rama, p. 108). See the discussion of Gen. 9:6, below, in the context of the punishment for murder; according to the standard rabbinic understanding of $\underline{b a}$ 'adam as 'by a human being', the verse emphasises the idea that violation of human society results in the killing of the violator at the hands of human society. See Qayin's concern that this will be his fate (Gen. 4:14); his crime is, perhaps, alluded to in Gen. 9:5-miyad ish achiv. Note that, if ba'adam is understood as 'by means of a human being', there is a juxtaposition in Gen. 9:5-6 between God seeking justice— $\underline{e} d r o s h$ and human beings carrying out justice by killing the criminal—ba'adam. (Such a reading raises the possibility that we might read the end of Gen. 9:6 - 'for in the image of God the human being was made'- not only as an explanation for why murder of a human being is 
Both of these conceptions of noachide law, however different they are from each other, are radically different from the rabbinic conception of sinaitic law. In sinaitic law, I argued in Part I of this study, commandedness is the essential characteristic; the prohibited act is criminal in that it is a violation of a command. ${ }^{34}$ In noachide law, commandedness is not the essential characteristic at all. ${ }^{35}$ For Tanna deVei Menashe, the laws are not commands; for the Rabbis, the laws are commanded, and law is enforced within a judicial system that is itself legislated, but prohibited acts are criminal in that they violate essential norms of behaviour within human society. ${ }^{36}$ Sinaitic law, also, is an articulated legal system, different in kind from the simple list of prohibitions (plus, for the Rabbis, the imperative of dinin) that constitutes noachide law. ${ }^{37}$ Unlike noachide law, sinaitic law recognises different punishments for different crimes; ${ }^{38}$ it includes minimum degrees of criminal activity below which

punishable by death — because the murdered human being is created in God's image — but also as an explanation of why the human being is to carry out the justice which God has just said is in God's domain - because the human being, having been created in God's image, has the responsibility to carry out justice. See Steinmetz, 'Vineyard'.) This juxtaposition of God's responsibility with human responsibility parallels the notion that vayetzav, God's command, generates the imperative of dinin, human judicial activity. See further n. 68, below.

${ }^{34}$ See below on murder as an exception to this generalisation.

35 Note that it is not necessary for a noachide to have had a hatra'a (warning) in order to be punished (bSan 57b; yKid 1:1/58c; Bereishit Rabba 34:14). Similarly, Maimonides, in Hilkhot Melakhim 10:1-2, distinguishes between two kinds of shogeig with respect to noachides: if the noachide did the act unintentionally, he is not to be punished; if he did the act intentionally but without intent to violate the law, of which he was ignorant, he is liable. The notion that ignorance of the law (omeir mutar) is not an excuse for violation of the law, unless we take that principle to be founded on the notion that it is one's responsibility to learn the contents of the law, correlates with the view of noachide law suggested here. Maimonides does say that the person ought to have learned the law, quoting bMak 9b, but, since this responsibility is limited to noachide law, it would seem to reflect the notion that the content of noachide law is something that one is simply expected to know. This is in stark contrast with sinaitic law, the content of which one might well not know and violation of which is only punishable when the stated intent is to violate the command (see 'Crimes and Punishments, Part I' and see further below, in relation to the laws of achoto and murder). Note that the sugya in bMak on which Maimonides seems to be basing his principle about the two different kinds of shogeig for noachides does not, in fact, make the distinction that Maimonides makes between excusable errors of fact and inexcusable ignorance of the law. For a review of the thorny issue of Maimonides' approach to the basis on which the noachide observes the noachide laws, see Stone, 'Sinaitic', pp. 1168-69 and see S. Schwarzschild, 'Do Noachites Have to Believe in Revelation?', Jewish Quarterly Review 52 (1961-1962), 297308, continued in vol. 53 (1962-1963), 30-65; Fox, 'Maimonides'; J. Dienstag, 'Natural Law in Maimonidean Thought and Scholarship (On Mishneh Torah, Kings VIII.11)', Jewish Law Annual 6 (1987), 64-77; O. Leaman, 'Maimonides and Natural Law', Jewish Law Annual 6 (1987), 78-93.

36 See Sifra on Lev. 18:4 and bYoma 67b for five of the Rabbis' seven noachide laws (all except for dinin and eating the limb of a living animal) as 'things that, had they not been written, it would have been reasonable for them to have been written' - this supports the notion that the criminal nature of these acts derives from their wrongfulness rather than from an awareness that one is violating a law. (See Fox, 'Maimonides', for an alternate understanding of this source.) It is, perhaps, noteworthy that, while the noachide laws are called mitzvot - 'commandments' - and the standard formula describes the noachides as having 'been commanded' - nitztavu — bAvoda Zara 64b uses the term 'accepted': 'whoever accepted upon himself the seven mitzvot that the noachides accepted upon themselves...' (see also bBava Qama 38a and bChul 92a).

37 Note the description of pre-sinaitic law as mitzvot golmiot in Shemot Rabba 30:9.

38 This includes crimes with penalties other than death as well as capital offences with different forms of capital punishment. In contrast, any violation of noachide law is punishable by death, 
the prohibited act is not punishable ${ }^{39}$ and it is particular-only those commanded at Sinai are bound by sinaitic legislation. ${ }^{40}$ This articulation underscores the fact that sinaitic law and sanctionability for its violation derives from and is shaped by legislation. ${ }^{41}$

Before moving on, I would like to address two possible arguments against the interpretation that I have offered of noachide law and its sanctions. First, some scholars have focused on the element of commandedness to argue against the notion that noachide law can be seen as a form of natural law, and so I want to highlight the distinction between the understanding of noachide law offered here and the position of those who see noachide law as deriving from command. ${ }^{42}$ My argument is that the commandedness of law, while a central component of the Rabbis' (but not of Tanna deVei Menashe's) position, does not negate the fact that the content of law is grounded in and limited by an understanding of what behaviour is essential for the maintenance of human society. In fact, the commandedness of the seven noachide laws-based, as it is, on God's command to the first human being as he is about to become a member of human society ${ }^{43}$ - might be seen to reflect less the notion of law as deriving authority from the command-er and more the notion that law is

and there is only one form of capital punishment for all crimes within each noachide system.

39 See bSan $57 \mathrm{a}-\mathrm{b}$ for the idea that any violation of noachide law is punishable by death, even, for example, stealing less than the value of a peruta, a degree of theft not actionable under sinaitic law. Stone, 'Sinaitic', sees the minimum degrees of criminal acts in sinaitic law as a dispensationa leniency granted to those who are in other ways bound to a more stringent system of lawrather than as representing the fuller articulation as a legal system of sinaitic law in contrast with the minimal legal character of noachide law, even according to the Rabbis' conception.

40 For the question of whether sinaitic legislation supercedes or supplements noachide law, see Stone, 'Sinaitic'.

41 An extended passage on marriage in Bereishit Rabba 18 (parellel in yKid 1:1/58b-c) highlights the distinction that I have drawn between noachide and sinaitic law. The passage makes the following points. (1) Based on 'and he shall cleave to his wife' (Gen. 2:24), a noachide becomes married only through the act of sexual intercourse; there is no legal state of betrothal (this is articulated in terms of the absence of sanctions for a man who sleeps with a woman betrothed to another man) for noachides. (2) Based on vehi be ulat ba ${ }^{\circ}$ al (Gen. 20:3), sexual intercourse creates a state of marriage even without legal intent. (3) There is no such thing as divorce for noachides (according to the primary interpretation which is offered and developed in the passage). (4) The forbiddenness of adultery, of homosexuality, and of bestiality derive from 'and he shall cleave to his wife'. (5) A noachide is culpable for anal sex with his wife- the point is made that prohibitions for noachides are not articulated as positive or negative commands; rather, this prohibition derives from 'and he shall cleave to his wife and they shall become one flesh' (the same verse given as the source of the rules in (1) and (2)). See the discussion of this passage in relation to Qumran and New Testament passages in A. Shemesh, '4Q271.3: A Key to Sectarian Matrimonial Law', JJS 49 (1998), 244-263 (section A). Sinaitic law differs on each of these points. (1) The legal act of betrothal creates the status of marriage (with attendant prohibitions and sanctions). (2) Sexual intercourse creates marriage only with accompanying legal intent. (3) The state of marriage can be dissolved by means of legal acts that effect a change in legal status (with attendant voiding of the prohibitions and sanctions brought into effect by the act of betrothal). (4-5) Acts are prohibited if and only if they are articulated as prohibited in a statutory formulation. In relation to the first three points, see H. L. A. Hart's discussion of the place of legal powers and 'powerconferring rules' within the framework of a positivist conception of law in The Concept of Law (New York, 1997), pp. 27-42.

42 See especially M. Fox, 'Maimonides'.

43 See n. 21, above. 
based on constraints required by entry into a relationship with others outside the self-that is, rather than it being a truly 'natural,' ontological component of the world as created (as in Tanna deVei Menashe's position), it is (according to the Rabbis' position) a prerequisite of human interaction with others in society. ${ }^{44}$ Thus, I have argued that the commandedness of law, for the Rabbis, is interrelated with the content of law, in that the very first command is dinin. In any event, whether or not we might see the content and the source of law as interrelated, I would still argue that commandedness as a feature of law should not be seen, within the Rabbis' position, as negating the importance of the content of the law as grounded in essential principles. (In fact, contemporary legal theories that are considered to fall under the category of natural law combine the notions of law as deriving from legislation and of the content of law as grounded in, justified by, or constrained by fundamental principles.) Thus, even the Rabbis' version of noachide law is radically different from the rabbinic understanding of sinaitic law, in which the essential characteristic is commandedness.

Second, it should not go unnoted that cheneq is both the mita for violation of noachide law according to the Tanna deVei Menashe conception and the default mita for violation of sinaitic law. This presents a challenge to my fundamental thesis that punishment is a reflection of a conception of law. Since my analysis of sinaitic law and Tanna deVei Menashe's version of noachide law suggests that these two conceptions of law lie on opposite ends of the jurisprudential spectrum, we should expect radically different, rather than identical, modes of execution for these two conceptions of law. I will offer two responses to this problem, though I am not sure that either is fully satisfactory. First, perhaps we should see violations of noachide law according to Tanna deVei Menashe as violations of God's will as incorporated in the created world, while violations of sinaitic law are violations of God's will as expressed in divine legislation. Thus, cheneq in each system represents the relinquishing of the God-given breath of life as a result of disobedience against God-God as legislator, in sinaitic law, and God as creator, in Tanna deVei Menashe's version of noachide law (both of which are different from the Rabbis' version of noachide law as situated within human society and, thus, as punishable by hereg). In the sinaitic system, though, we might see this as relinquishing a right to life by violating God's command, while in the noachide system we might see this as an un-creation of life resulting from violation of the 'laws' of creation.

We might also take into account the economy of mitot beit din noted in Part I of this study: the Bavli is constrained by earlier sources to consideration of four modes of execution, and seqila and sereifa have already been limited to a small range of crimes. While this might bring us back to the intriguing question of why the penalties of seqila and sereifa are so limited in application, ${ }^{45}$ it in any event leaves only hereg and cheneq as candidates for a

\footnotetext{
44 Such a notion would be comparable to the conceptions of natural law as law of the state in the writings of Hobbes and Locke; see Weinreb, Natural Law, pp. 68-83.

45 Sereifa only to those cases specified in the Torah-see 'Crimes and Punishments, Part I',
} 
penalty that is to be applied broadly within a system of law. And these two mitot are already seen as applied broadly, hereg as the mita imposed by secular authorities ${ }^{46}$ and cheneq as the default mita for sinaitic law. Thus, short of reversing the tendency to limit seqila and sereifa or of introducing an additional mode of execution beyond the traditional four, the Bavli is limited in its discussion of noachide law to hereg and cheneq, and it assigns one of these to each version of noachide law, as best corresponds to the respective conception of law.

I would like to turn, now, to look at one particular sinaitic law in order to highlight the distinction between rabbinic conceptions of sinaitic and noachide law. Then, I will focus on one law that seems to be exceptional within the sinaitic system - the law of murder - to show how a law which is seen to be different in its nature as a law is assigned a different punishment from other laws within the sinaitic system, a punishment that reflects the different nature of this law and its violation.

\section{A Paradigmatic Sinaitic Law}

To sharpen the distinction between noachide law and sinaitic law, I will look at a particular law that is stated in the Torah and at some of the legal principles derived from that statement in rabbinic sources. Within the list of forbidden sexual relationships in Lev. 18 and 20, the Torah includes the prohibition of a man sleeping with his sister. The prohibition is stated in Lev. 18:9: 'The nakedness of your sister, the daughter of your father or the daughter of your mother, born at home or born abroad, you shall not uncover their nakedness.' The law is restated in a casuistic formulation in Lev. 20:17: 'And a man who takes his sister, the daughter of his father or the daughter of his mother, and sees her nakedness, and she sees his nakedness, it is chesed, and they shall be cut off in the eyes of the members of their people; he has uncovered the nakedness of his sister - he shall bear his iniquity.'

Like the other prohibited relationships that are included in both chapters 18 and 20, the law of achoto - 'his sister' - raises the question of why the Torah needed to state this law twice, once as a command prohibiting the act and once in a casuistic formulation stating the penalty if the act is committed. But, besides this, the second verse raises several other questions addressed in rabbinic texts: If the verse has already stated that the man has taken his sister who is his father's daughter or his mother's daughter, then why need it repeat that he has uncovered the nakedness of his sister? Why does this verse, in contrast to the preceding verses that describe the commission of other prohibited acts, mention the penalty of kareit - being 'cut off'? Why is the act described as the 'seeing of nakedness' on the part of both the man and the woman, in addition to its description as the 'uncovering of nakedness', the term that is used to describe the prohibited acts in the neighbouring verses and in the

n. 78 - and seqila to a handful of others - see 'Crimes and Punishments, Part I', n. 38 for details and for the hypothesis that seqila is the default biblical mode of execution.

46 See nn. 88 and 89 , below. 
prohibitions of chapter 18? And, most obviously, what does the Torah mean by saying of this particular act: 'it is chesed'?

Based on each of these anomalies, rabbinic sources derive principles that are fundamental to the jurisprudence of sinaitic law. As discussed in Part I of this study, rabbinic sources take for granted that, in order for an act to be punishable, the Torah needs to include both an azhara - a command not to do the act - and an onesh - the statement of a sanction for violation of the command. Lev. 18, indeed, contains a list of azharot, while Lev. 20 contains a list of sanctions. The verses about achoto, though, are used to establish an additional pair of principles: that neither an azhara nor an onesh can be derived based on logical inference. ${ }^{47}$ The fact that the Torah must state 'his sister' in addition to 'his father's daughter or his mother's daughter,' even though it would seem obvious that the prohibition and punishment would apply to one's full sister if they apply to one's half-sister, is taken to teach that no act is punishable unless the Torah states a prohibition and punishment for that very act, no matter how reasonable it might be to deduce such a prohibition and punishment without that statement.

The mention of kareit in Lev. 20:17 is the locus of discussion of several questions related to punishability: whether a crime with the sanction of kareit is punishable in a human court with malqot; whether a single act that violated multiple prohibitions is punishable as one or several crimes; whether multiple acts committed in a single time-span of ignorance of the law or of error concerning the circumstances is to be considered one or several unintentional transgressions. ${ }^{48}$

The inclusion of the phrase 'and sees her nakedness' in Lev. 20:17 is cited in the Bavli as the first of several sources for the requirement of a warninghatra' $a$ - in order for an act to be punishable: 'Is the thing [=the act] dependent on seeing?! - rather [the phrase comes to teach us that he is not pun-

47 Lev. 18:9 is cited as the source of the principle ein mazhirin min hadin in Sifra Qedoshim 10:12 on Lev. 20:17 (92b), bYev 22b, and bMak 5b. The principle is mentioned several other times in the Bavli, but no other verse is ever cited as its source. Lev. 20:17 is cited as the source of the principle ein onshin min hadin in Sifra Qedoshim 10:10 on Lev. 20:17 (92b), bMak 5b and 14a, and bKer 3a. Midreshei halakha on several other verses include an argument of the same form as the Sifra's comment on Lev. 20:17: a suggested logical inference of an onesh, the objection 'if you say thus, then you have punished based on a logical inference', and, finally, a statement that the verse that the midrash is addressing comes 'to teach you that we do not punish based on a logical inference'. See Mekhilta deRabbi Yishma'el, Neziqin 7 (pp. 272-273), 11 (p. 288), 12 (p. 291), Sifre beMidbar 1 (ed. Horovitz, p. 2), 23 (p. 28), Midrash Tanaim, Deut. 17:2 (p. 99). In each of these cases, though, while the biblical phrase is stated to be the source of the principle, the principle actually functions to justify the Torah's inclusion of the phrase in question - that is, the principle is invoked to solve an exegetical problem, rathen that the verse being invoked to generate the priniciple. The situation in the Bavli is different in two ways: first, Lev. 20:17 is the only verse cited as the source of the principle; second, the claim is made that the purpose of the word achoto is to teach you this general principle - see bKer 3a and, especially, bMak 5b, where Lev. 20:17 is not the verse under discussion; it is cited because it is the source of the principle which is being invoked in the context of a different law entirely. Thus, while there is a strong link between the achoto verses and this pair of principles in earlier sources, it is in the Bavli that the biblical verses concerning the law of achoto are seen as formulated to generate these fundamental principles of sinaitic positive law.

48 See bMak 14a and 23b and bKer $2 b$. 
ishable] until they cause him to see the basis of the thing. ${ }^{49}$ Lev. 20:17 is also cited as the first answer in the Yerushalmi to the same question about the source of the requirement of hatra' $a$, but here the requirement is more obliquely derived from the words 'it is chesed'.$^{50}$ The Yerushalmi goes on to cite the following teaching: 'Qayin married his sister; Hevel married his sister-I [says God] did an act of kindness (chesed) with the first ones so that the world would be built from them- "For I said: The world shall be built through chesed" (Psalms 89:3).' While the Yerushalmi's argument is not entirely clear, ${ }^{51}$ I would suggest the following understanding: Why does the Torah need to say, in connection with the law that a man who sleeps with his sister has committed a punishable offence, that this act is chesed? Because the would-be committer of this act is aware that humankind began with brothers sleeping with their sisters - that, in fact, this is world-building behaviour. So God tells the would-be committer that, although in truth humankind did originate from brother-sister intercourse and although this act is indeed world-building, this act is now prohibited and the person who commits this act is to be punished. According to this understanding, the Yerushalmi's derivation of the requirement of hatra' $a$ is similar to the Bavli's: this verse is telling us that we need to make sure that the would-be violator knows that the act is prohibited, because he has good reason, in fact, to think that it is permissible. $^{52}$

A similar teaching about humankind beginning with brother-sister intercourse occurs in the Bavli in the context of a dispute about which sexual relationships are forbidden to a noachide. ${ }^{53}$ Some say that a noachide is permitted to sleep with his paternal sister but not with his maternal sister, while others say that even a maternal sister is permitted to a noachide. The gemara then cites the teaching about Qayin to suggest that this was a one-time dispensation, which would imply that, in general, a noachide cannot sleep with his maternal (or full) sister. This argument is rejected by the gemara: 'once it was permitted, it was permitted'-behaviour that is permissible at the beginning of time remains legitimate for all time.

The question of brother-sister intercourse, then, seems to represent a crit-

49 ad sheyar'uhu ta'amo shel davar (bSan 40b) — the fact that the act is prohibited or, perhaps, the source of the prohibitedness of the act.

50 ySan 5:1/22c.

51 The Penei Moshe on this passage takes the Yerushalmi to be deriving hatra'a from Lev. 20:17 in the way the Bavli does, from 'and he sees'. The mention of 'it is chesed' and the teaching about Qayin and Hevel he sees to be brought in tangentially as an unrelated teaching on this verse; this teaching does, in fact, occur in a different context in yYev 11:1/11d.

52 Sifra Qedoshim 10:11 on Lev. 20:17 (92b) first cites 'and he sees ... and she sees' to teach that they are not culpable unless they act bemeizid. Immediately following that, the Sifra cites 'it is chesed' and comments: 'and lest you say: Qayin married his sister-Scripture teaches "it is chesed" - and the world at its beginning was built only through chesed ...' The juxtaposition here of the derasha on 'and he sees ...' and the derasha on chesed seems to suggest the kind of argument that I am suggesting for the Yerushalmi: you must understand that this is forbidden, and I can see why you might think it is not forbidden, based on the example of Qayin, so let me explain that the example of Qayin should not lead you to think that I permit this behaviour now.

$53 \mathrm{bSan} 58 \mathrm{~b}$. The dispute is introduced at the bottom of $57 \mathrm{~b}$ and is attributed, within the sugya, to R. Eliezer and R. Aqiva - the former forbidding a maternal sister and the latter permitting. 
ical divide between noachide and sinaitic law in two different, but related, ways. First, rabbinic sources recognise that, from a natural law perspective ${ }^{54}$ there is nothing wrong with brother-sister intercourse. ${ }^{55}$ On the contrary, at a certain point in time - the beginning of human history - brothersister intercourse was a necessary act; far from being world-destroying behaviour, like Tanna deVei Menashe's forbidden acts, or behaviour antithetical to the construction of human society, ${ }^{56}$ like the Rabbis' prohibitions, brothersister intercourse was a world-building act: 'The world shall be built through chesed ${ }^{57}$ Hence, within noachide law, there is not an absolute prohibition of achoto.

Second, the verses about the prohibition of achoto serve as the source for several general principles of sinaitic law. These principles relate specifically to elements discussed in Part I of this study as representative of the positivist nature of sinaitic law, especially ${ }^{58}$ the requirement that there be an explicit azhara and an explicit onesh and the requirement that there be a hatra' $a$ in order for the offender to be punished for the act. Thus, achoto represents a convergence of critical substantive and procedural elements of the rabbinic conception of sinaitic law, for in achoto we have an act that is a violation of positive law but not of natural law, and it is from the formulation of the law of achoto that we derive principles central to the jurisprudence of sinaitic positive law: an act is forbidden because a command prohibits it, it is sanctionable because the law states the sanction, and a violator is punishable only if he is aware that he is violating a command punishable by the stipulated sanction. ${ }^{59}$

\footnotetext{
54 Again, I am using the term 'natural law' only to suggest the conceptions that I have presented above as characterising the two approaches to noachide law developed in the Bavli.

55 In rabbinic sources, brother-sister intercourse is sometimes presented as something likely to occur, if only by virtue of the proximity of the people involved; see, for example, bNaz 23a, bKer 17b. Rabbinic sources, of course, see as desirable a man marrying his sister's daughter, just one step away from the prohibited relationship; see, for example, mNed 8:7 and 9:10, yYev 13:2/13c, bYev $62 \mathrm{~b}$, bGit $17 \mathrm{a}$, bSan $76 \mathrm{~b}$.

56 Note that, in the Bavli, this act is allowed within a social context-Adam allows Qayin to do this; thus, Qayin's act not only allows the generation of human society, it is an act encouraged within human society.

57 In the Yerushalmi passage, the chesed is God's kindness in having permitted this act. In the Bavli passage, the chesed appears to be Adam's, in allowing Qayin to take his sister rather than Adam taking his daughter for himself, as well as, perhaps, God's, in allowing this act. (See Rashi on bSan 58b, s.v. chesed yibane and Yad Rama, p. 111.) In the Sifra passage discussed in n. 52, above, it is not clear whose chesed is being referred to; quite possibly chesed is being taken here to describe the nature of the act of brother-sister intercourse (see also Gen. 20:13), through which the world was built.

${ }^{58}$ Questions about punishability and, in particular, about the relationship between punishability and awareness of the crime, such as those mentioned above in relation to the achoto passage (see text at n. 48), also fit the positivist model. Note also that the law of achoto is the locus for the extended discussion in bKet (beginning on $31 \mathrm{~b}$; see especially the attempted proof from Lev. 18:9 on $32 \mathrm{~b}$ ) about whether a person can both be punished with malqot and be required to pay a penalty for a single crime.

59 Awareness of the prohibition of achoto is presented within a rabbinic idiom as a paradigm for that which is clearly known: '.. if the thing is as clear to you as your sister that she is prohibited to you, say it, and, if not, don't say it.' See, for example, bShab 145b, bSan 7b.
} 


\section{An Exceptional Sinaitic Law}

If the law of achoto can be seen to represent the disjunction between the noachide and sinaitic systems, a different law seems to stand at the intersection between these two systems. Murder is the one crime that the rabbinic system assigns to the execution of hereg ${ }^{60}$ all other crimes for which the Torah does not state a mode of execution are either assimilated to the category of crimes punishable by seqila or assigned to the default mita of cheneq. From the perspective of its punishment, then, murder stands out as unique within the sinaitic system. In contrast, within each of the conceptions of noachide law presented in the Bavli, murder shares the same punishment as every other violation of law; in fact, as the one noachide criminal act for which the Torah describes the consequences, ${ }^{61}$ murder can be taken to be paradigmatic for crime and punishment within a system of noachide law. If murder results in cheneq, as Tanna deVei Menashe would say, then all violations of noachide law result in cheneq; if murder is punishable by hereg, then all noachide crimes are punishable by hereg, as the dominant position holds them to be. ${ }^{62}$ The unique punishment of murder within the sinaitic system by hereg invites us to look at the crime of murder and see whether, first, it is seen as different in kind from other prohibited acts within the sinaitic system and, if so, whether its sanction of hereg can be seen as reflecting the particular nature of this act and as linking murder to the dominant rabbinic conception of noachide law.

Within biblical law, murder is unique among crimes in that the act has an essential reality distinct from the legal responsibility of the perpetrator ${ }^{63}$ and the possibility of bringing the murderer to justice. Murder is a wrong that has been done, and the wrong needs to be addressed. Thus, the Torah includes the ritual of the egla arufa, a ritual designed to atone for the spilling of a murder victim's blood when the murderer cannot be identified ${ }^{64}$ Murder, according

60 The other crime punishable by hereg is ir hanidachat (mSan 9:1), but this is already stated in the Torah (Deut. 13:16). See 'Crimes and Punishments, Part I', n. 15, about whether the Torah's command to kill the inhabitants of ir hanidachat by sword ought to be seen as a judicial punishment.

${ }^{61}$ Gen. 9:6. It is not entirely clear what those consequences are; see n. 68, below.

${ }^{62}$ For the sources of these punishments for violation of noachide law, see n. 33, above.

${ }^{63}$ One indication of this unique feature of murder is the law of the city of refuge which, while designed to protect the unintentional murderer from being killed by the go'eil hadam, includes also the element of atonement and the element of exile. See Num. 35:31-32, where it is forbidden to take ransom whether in place of executing the intentional murderer or in place of the unintentional killer going to the city of refuge. See below on exile as the primordial punishment for murder. The elements of atonement and exile are highlighted in rabbinic discussions of the city of refuge. A result of seeing exile to the city of refuge as atonement is the development, within rabbinic sources, of categories of killers who do not go to a city of refuge: someone who kills by a completely unforeseeable accident and someone who bears a significant measure of responsible for the killing. The former does not require atonement, and the latter does not deserve it. Note that, within the latter category, is the person who is not aware that killing is prohibited - see n. 87, below. On the different biblical passages about the city of refuge and their different foci, see M. Greenberg, 'The Biblical Concept of Asylum', Journal of Biblical Literature 78 (1959), 125-32, and A. Rofe, 'On the Origins of the Cities of Refuge in Biblical Law' (in Hebrew), Beit Miqra 31 (1985-1986), 110-33.

64 Rabbinic sources insist that, if the murderer is later identified, he must be killed nevertheless; thus, the issue of bringing the criminal to justice is not identical to the issue of atoning for the 
to Num. 35:33-34, pollutes the land - the land in which the people of Israel lives and in which God dwells. ${ }^{65}$ And thus, killing the murderer, if the murderer is known, cannot be seen simply as imposing a sanction for violating a command. The murderer, rather, has violated the world in which he livesthe land, the people, and God (Num. 35:34) - and that violation requires the spilling of the murderer's blood-'and the land cannot be atoned for, for the blood that is spilt in it, but by the blood of its spiller' (Num. 35:33) ${ }^{66}$

Num. 35:33 clearly echoes Gen. 9:6 ${ }^{67}$ - $'$ He who spills the blood of a human being, by ${ }^{68}$ a human being shall his blood be spilt'-God's words to Noach's sons, and a verse to which we shall return shortly. But the notion of murder as a violation of the world that ought to require the killing of the murderer comes up even earlier in the Torah, with the first homicide, Qayin's killing of Hevel. While God describes the effect of this murder as a violation of the land that results in an alienation of the human being from the land

spilling of the victim's blood. If, however, the murderer is known at first, there is no need for a separate atonement ritual, as the killing of the murderer serves also to atone for the spilling of blood. See Sifre beMidbar, p. 222, tKer 4:3, bKet 37b, and bSota 47b, which derive the former law from Num. 35:33, and ySota 9:6/23a, Rashi on Deut. 31:9, and Maimonides, Hilkhot Rotzeach $10: 8$, for a derivation from the verse that concludes the egla arufa passage. See below for how the Bavli sees the egla arufa ritual as informing the procedure for execution of a murderer.

65 Other crimes, especially sexual offences, also affect the land and the people's ability to remain on the land - see, for example, Lev. 18:25-28 - but murder is unique in that atonement is required for the land. For some examples of the juxtaposition of murder and sexual offences, see Ezek. 16:38, 22:1-13, and 23:45 and the exegesis of Deut. 22:26 in bSan 73a.

66 See Sifre beMidbar (p. 220) on why the unintentional murderer must stay in the city of refuge until the death of the high priest (Num. 35:25): 'Rabbi says: A murderer defiles the land and causes the divine presence to depart, and a high priest causes the divine presence to rest on the human being in the land; it is not reasonable that the person who defiles the land and causes the divine presence to depart be in the presence of the person who causes the divine presence to rest on the human being in the land.' See Devarim Rabba 2 on murder as the only crime (that is, the only violation of the six mitzvot commanded to Adam) which cannot be forgiven-the murderer's blood must be shed; see the story told there about the seething blood of a murder victim which is calmed only when the murderer has been killed.

${ }^{67}$ See Y. Lorberbaum, 'Blood and the Image of God-The Punishment of Beheading in Early Rabbinical Literature' (in Hebrew), Mechqerei Mishpat 15 (2000), 429-56.

68 The meaning of $\underline{b a^{\prime} a d a m}$ in this verse has been the subject of dispute from ancient times to the present. See n. 33, above, for an exegesis in bSan $57 \mathrm{~b}$ which takes this preposition to mean 'within', and note also the interpretation in bSan 58b that, parsing the verse differently, takes ha'adam $\underline{b a}$ 'adam to refer to the killing of a foetus, a human being 'within' another human being. The standard rabbinic understanding of $b a$ - is 'by means of' (see, for example, the comment of Rashi on bSan 56a, cited in n. 33, and a variety of classical midrashim, commentaries, and targumim). An alternate rendering of $b a$ - is 'instead of/on account of' (see LXX) - that is, that the murderer's blood is to be spilled on account of the human being who has been murdered, a reading which leaves the subject of the spilling of the murderer's blood unstated and which, possibly, clears up the fact that the previous verse has God as the seeker of justice (see n. 33 for an understanding of the relationship between these two verses according to the reading of $b a$ - as 'by'). For these two readings argued by contemporary scholars, see the dispute between B. Jackson, Essays in Jewish and Comparative Legal History (Leiden, 1975), pp. 46-47, and M. Greenberg, 'More Reflections on Biblical Criminal Law', in Studies in Bible, Sarah Japhet, ed. (Jerusalem, 1986=Scripta Hierosolymitana 31), pp. 15-16 and nn. 29-30. In any event, it seems clear that Num. 35:33 is reading Gen. 9:6 as requiring a human being to shed the blood of the murderer. Since this is the standard rabbinic interpretation of Gen. 9:6, as noted, it is reflected in my translation and discussion of this verse as a key part of the biblical background to the rabbinic treatment of murder and its consequences. 
(Gen. 4:10-12), Qayin elaborates further on the consequences of his deed: he has been chased off the face of the earth, he will be hidden from God's face, and, finally, 'anyone who finds me shall kill me' (Gen. 4:14). ${ }^{69}$ Once again, homicide is portrayed as an act that has an effect on the human being's relationship with the land, with God, and with fellow human beings. The result that Qayin anticipates, but from which God protects him (Gen. 4:15), is that he will be killed for killing his brother. This protection is denied the murderer in God's words to Noach and his sons after the Flood ${ }^{70}$ in Gen. 9:6, a verse which is echoed, as noted, in the Torah's injunction in Num. 35:33-34 to restore the land in which the people live and in which God dwells by spilling the blood of the murderer.

It is noteworthy in this regard that the Torah does not see the 'redeemer of blood' - go'eil hadam - as an individual who functions wholly outside of the system of justice, as someone who attempts privately to redress a private wrong done to his kinsman whether purposely or inadvertently. While the go'eil hadam does seek the death of the killer and might, in fact, kill him without the mandate of the communal authorities, the Torah additionally portrays the go'eil hadam as someone who has a legal claim against the murderer $^{71}$ (Num. 35:24) and as the person into whose hands the murderer is delivered if determined to be guilty ${ }^{72}$ (Deut. 19:11-12). The notion of a human being spilling the blood of the spiller of blood, then, forms the backdrop of and constitutes a component of the community's formal response to this act which has violated the life of the community. ${ }^{73}$

Without attempting to analyse further the biblical understanding of the nature of the act of murder, of the consequences of this act, and of how killing the murderer restores the disruption effected by the act of murder ${ }^{74}$ my goal

${ }^{69}$ For a discussion of Qayin's elaboration of the consequences of his act, see Steinmetz, 'Vineyard'.

70 Note the mention of 'his brother' in the preceding verse; see n. 33, above. For a discussion of this passage as representing a shift in human responsibility and in governance of the world after the Flood, see Steinmetz, 'Vineyard'.

71 Compare the conception of the go'eil hadam as a plaintiff who loses if the person on trial for murder is found innocent in bSan $37 \mathrm{~b}$; the notion of a plaintiff who loses if the defendant wins is seen as unique, within trials for capital offences, to the case of murder. See n. 86, below, for the idea that serving as plaintiff is the one of the central roles of the go'eil hadam for the purpose of which the court must appoint a surrogate go'eil if no go'eil exists.

72 See below on the role of the go'eil hadam in rabbinic sources and on the go'eil hadam as a possible paradigm for the judicial and communal response to murder.

73 The term go'eil hadam underscores the notion of restoration effected by the punishment of the murderer; compare the go'eil in Lev. 25 and the idea of returning to one's portion of land in Lev. 25 and in Num. 35:28. My thanks to David Silber for this point.

${ }^{74}$ For one such analysis and a discussion of some of the literature related to this subject, see Lorberbaum, 'Blood'. Lorberbaum sees the blood specifically as incorporating the human being's shared essence with God, a view that I do not share. On the contrary, blood seems to represent, in the Torah, the life-force that human beings share with other living creatures. Animal blood, thus, must not be consumed by a human being; it must either be returned to God, by being put on the altar, or returned to the earth. (See Ezek. 34:6-8 for blood that is left exposed; note that here pouring blood on the earth is equivalent to - or leads to - the blood being covered. For the difficulties in interpreting and reconciling the laws concerning slaughtering of animals and treatment of the blood in Lev. 17 and Deut. 12 and the differences in the way these laws were understood 
here is simply to establish two points about how murder is seen in the Torah: first, that it is an act the commission of which leaves a real mark on the world; second, that it is an act that of necessity ought to result in the killer's killing by a fellow human being.

Both of these elements are retained in rabbinic sources about murder and the punishment of a murderer. Addressing the mishna's statement that a murderer is executed by hereg, the Bavli ${ }^{75}$ cites a baraita that gives as the source of this law the Torah's statement that a person who kills a slave naqom yinaqeim - 'shall surely be avenged' (Ex. 21:20) - a term that is then interpreted by reference to the phrase cherev noqemet - 'an avenging sword' (Lev. 26:25). That 'vengeance' is the source of the judicial execution of hereg for a murderer suggests that, at its core, murder is an act that demands a human response - the killer has killed a human being, and a human being will kill the killer. ${ }^{76}$ The Bavli goes on to cite a second baraita in response to the question

in rabbinic and Qumran texts, see C. Werman, 'The Law of Covering Blood and Eating It in Priestly Halakha and the Halakha of the Sages' (in Hebrew), Tarbiz 63 (1994), 173-83. For the suggestion that the understanding of blood underwent a transformation in the rabbinic period, see N. Zohar, 'Ancient Rituals Transmitted by R. Judah-Evidence of a Transformed Understanding of "Blood is Life"' (in Hebrew), Tarbiz 58 (1989), 525-30. On the significance of blood in the primeval narrative, see T. Frymer-Kensky, 'The Atrahasis Epic and Its Significance for Our Understanding of Genesis 1-9', Biblical Archaeologist 40 (1977), 147-55.) But the fact that this animating substance is shared by animals and human beings suggests that we cannot look to this substance as the locus of tzelem elohim. See Gen. 9:3-6, where all blood is off-limits, but only the human being's blood can't be shed; if it is shed by a human being, then that person's blood is shed, because the human being is created in tzelem elohim. It cannot be, then, that blood is the locus of the human being's shared essence with God, since the special quality of blood is shared by human beings and animals, while tzelem elohim is unique to human beings. In fact, neither passage that describes the creation of the human being - neither Gen. 1, where tzelem elohim is mentioned but the materials out of which the human being is created are not, nor Gen. 2, where the materials are mentioned but tzelem elohim is not-includes any mention of blood.

75 bSan 52b, commenting on mSan 9:1.

76 This reciprocity is suggested by the phrase yirtzach et harotzeach (Num. 35:30) in addition to the biblical sources mentioned above (see G. Blidstein, 'Capital Punishment-The Classic Jewish Discussion', Judaism 14 (1965), 159-71, n. 7); see Mekhilta deRashbi, p. 169 and the baraita in ySan 7:3/24b. See A. Shemesh, 'Eilu Hen haNeheragin: Iyun bePereq miTorat ha'Onshim Shel Chazal', Shenaton haMishpat ha'Ivri 21 (1998-2000), 267-90, for the hypothesis, based on a reading of the tannaitic sources (see the sources cited in the preceding note), of an early rabbinic position that the murderer was to be killed in the way that he killed. Whether or not the sources suggest that such a position was in fact maintained, they certainly present such a position as a theoretical possibility (such an idea occurs in non-rabbinic sources; see Jubilees 4:31-32 and see Aptowitzer, 'Observations'; Albeck, Seder Neziqin (Jerusalem and Tel Aviv, 1953), p. 453; and S. Kraus, 'Pereq biYsurei haGuf', Devir 1 (1923), 88-112); see especially Mekhilta deRashbi, p. 169 and ySan 7:3/24b, the two sources which work with yirtzach et harotzeach. And perhaps we should read the conclusions of these baraitot, that the murder is to be 'avenged' by sword, as sustaining the notion of reciprocal vengeance but generalising and institutionalising it in the form of hereg - the paradigmatic way that human beings kill. (See below on the degree to which the execution of the murderer may not, in fact, be fully institutionalised and formalised.) P. Segal argues the exact opposite, that the citation of the 'cherev noqemet' brought by God in Lev. 16:25 suggests that, in hereg - as, he argues, in all other forms of mitat beit din-judicial execution is understood in rabbinic texts as similar to ways in which God kills and as having the function of atonement; he sees this as a rejection of an older talionic view. For Segal, then, the two derivations of hereg discussed in the preceding note both emphasise atonement, rather than highlighting two aspects of the sanction for murder, as I have argued; see 'Chiyuv biYdei Shamayim': Chiyuvei Mitot Beit Din veChiyuvei Mita leShamayim, PhD dissertation, Hebrew University (Jerusalem, 
of how, according to the position that hereg is more lenient than cheneq, one could conclude that someone who kills a free person is still executed by hereg, like someone who kills a slave, rather than by the more severe cheneq. This second baraita derives hereg as the punishment for murder from the ritual of the egla arufa. The two baraitot cited in the Bavli as sources for hereg as the punishment for a murderer, then, highlight the two points stressed here: that murder is a crime whose commission results in an essential reality that requires atonement (egla arufa) and that murder demands vengeance (naqom yinaqeim) - the killing of the killer. ${ }^{77}$

A striking indication that judicial execution of the murderer is seen, within rabbinic sources, as the institutionalisation of society's response to the effects of a crime against society, rather than as a purely judicial sanction for violating a sinaitic command, is in the hatra'a that is mentioned in a number of rabbinic sources that describe commissions or would-be commissions of murder. As we have seen, the requirement of a hatra' $a$ underscores a fundamental premise of sinaitic jurisprudence, that a criminal is punished for intentional violation of a sanctionable command. We would expect, then, that the $h a-$ tra' $a$ for murder would include reference to a statute addressed to Israelites forbidding murder and to the punishment that the law stipulates for violation of this statute. But the hatra'a, instead, is this: 'See- he is an Israelite and a member of the covenant, and the Torah has said "He who spills the blood of a human being, by a human being shall his blood be spilt." 78 The verse describes, or perhaps prescribes, the consequence of murder, but it does not have a legal formulation as the statement of a prohibition - such as 'thou shalt not commit murder' (Ex. 20:13) — with the attendant punishment—such as 'the murderer shall surely be put to death' (Num. 35:16). In fact, this verse is not even addressed to Israelites; it is a passage with universal application. ${ }^{79}$ Further, it is a text that highlights the reciprocal nature of the consequences of murder; the chiastic structure of the passage suggests that the killer, of necessity, is to be killed by a fellow human being. And, finally, this is the paradigmatic noachide verse: spoken by God to Noach and his sons and addressing the consequences of a criminal act, this verse is seen as the paradigm for punishment within noachide law. ${ }^{80}$

1986), p. 116 and 'Postbiblical Jewish Criminal Law and Theology', Jewish Law Annual 9 (1991), 107-21. For the juxtaposition of murder and neqama in the story of the first murder in the Torah, see Gen. 4:15, 24.

77 See also ySan 7:1/24b and 7:3/24b, Mekhilta deRabbi Yishmael, Neziqin, pp. 261-62 (here the initial derivation of hereg is from Gen. 9:6) and p. 273, Mekhilta deRashbi, p. 169.

78 Mekhilta deRabbi Yishmael, Kaspa 20 (p. 327), tSan 11:4, ySan 5:1/22d, bSan 72b and see Avot deRabbi Natan a, 16. This verse is also cited as the source for the onesh for murder in Mekhilta deRabbi Yishma'el, baChodesh 8 (p. 232). In Mekhilta deRashbi on Ex. 20:13 (ed. Epstein-Melamed, p. 152), though, the passage that serves as the source for the onesh is the much more likely mot yumat harotzeiach (Num. 35:16).

79 It is especially striking that the hatra' $a$ begins with a statement that the intended victim is an Israelite, a prerequisite for punishment of the murderer by the beit din, and yet goes on to cite a verse that reflects a universal context.

80 See n. 33, above. One could argue that the citation of this verse has nothing to do with the elements noted here, that it is cited simply because it is more explicit about the mode of execution than any alternate verse: 'his blood shall be spilt' implies hereg. Reference within the hatra'a 
The nature of the execution of a murderer as a punishment imposed within human society rather than as a purely judicial sanction is also suggested by several specific laws about how a murderer may be killed. For example, while a murderer is to be executed by means of hereg, if the court is unable to implement this form of execution, it is mandated to execute the murderer in any way it can.$^{81}$ If a murderer cannot be convicted because there are no witnesses, he is nevertheless punished by placement in kipa. ${ }^{82}$ If there is no go'eil hadam to kill the murderer, another person is appointed in the go'eil hadam's stead. ${ }^{83}$ These irregular allowances suggest that murder is not uniquely a crime within the sinaitic system of law to be addressed solely within the constraints of the sinaitic system of judicial procedure. Murder is a crime against society, and, while the court is mandated to punish the murderer, judicial punishment does not replace civil society's sanctions against the murderer. Rather, the court's role is to implement those sanctions, and there is ample room to dispose of the murderer if the court cannot do it within its regular procedures. ${ }^{84}$

to the specific mode of execution is required by R. Yehuda in bSan $8 \mathrm{~b}$ and $80 \mathrm{~b}$ (R. Yose beR. Yehuda in tSan 11:1). But, even according to this opinion, it would presumably suffice to state the punishment without reference to an explicit biblical text; otherwise, it would be impossible to give a hatra' $a$ for most capital offences, since most do not have the mode of execution explicitly specified in the Torah.

81 bSan 45b, 53a, 72b; see also bBava Metzia 31b and n. 85, below.

$82 \mathrm{mSan}$ 9:5. While this could be seen as a form of restraint - essentially, imprisonment of the criminal for the protection of society - the Bavli sees this as a way of killing the murderer outside of the rubric of the arba mitot (bSan 81b). In the mishna, murder is the only capital offence for which kipa is mandated if the person cannot be prosecuted because of lack of witnesses. (Kipa is also mandated for repeat committers of non-capital offences in mSan 9:5, though how the person is treated in the kipa is described differently in these two mishnayot. The Bavli, though, takes the treatment of the two kinds of criminals to be the same. For a discussion of the two cases of kipa in this mishna, see B. Jackson, Essays in Jewish and Comparative Legal History, pp. 187-93.) In contrast, the Tosefta (tSan 12:7) mandates kipa for all repeat violators of capital offences who cannot be prosecuted under regular judicial procedure; it does not single out the murderer. (The Bavli interprets this source as referring to non-capital offences.) Similarly, the Tosefta (tSan 12:6) says that a person condemned of any capital offence can be killed in any way, if the court is unable to impose the mandated form of execution; the Tosefta cites uvi arta hara miqirbekha as the basis of this mandate. In contrast, the Bavli limits this mandate to the crime of murder (see sources cited in preceding note). (Maimonides, Hilkhot Rotzeach 4:8-9, follows the mishna and Bavli in limiting kipa to murder, commenting that no other crime entails hashchatat yishuvo shel olam as murder does. On the other hand, Maimonides rules in Hilkhot Sanhedrin 14:8 that a criminal convicted of any capital offence can be killed in any way necessary. See the commentaries on the difficulty of reconciling this position with the Bavli. Maimonides does distinguish, however, between murder and other capital offences with regard to who can implement the execution; only for murder can anyone kill the criminal if he cannot be killed by the designated executioner-see Hilkhot Rotzeach 14:8 and 13:1. See below, n. 86, on who is to kill the murderer. As noted in 'Crimes and Punishments, Part I', n. 5, Maimonides also cites murder as the crime that a king is mandated to punish, if it is not punishable by the beit din; see especially Hilkhot Rotzeach 2:4 and Hilkhot Melakhim 3:10, in both of which Maimonides cites the goal of tikkun olam, the rectifying of the destruction mentioned in Hilkhot Rotzeach 4:9.) It is only in the Bavli combined with the mishna, then, that unique to murder - as opposed to other capital offences - are all three dispensations: killing in any way, killing by anyone, and condemnation to kipa in the absence of witnesses to the crime.

${ }^{83}$ bSan 45b; see Sifre Devarim 186-187 (ed. Finkelstein, p. 226). See below, n. 86, on what function of the go'eil hadam is referred to in this provision.

84 The first and third laws mentioned here are juxtaposed in the Bavli (bSan 45b and 72b) in 
In fact, the very punishment that the court is mandated to implement suggests that, in essence, punishment of the murderer is an irregular procedure, even when accomplished within the regular workings of the judicial system. ${ }^{85}$ Hereg, as noted above, is the way people kill. Killing by sword is a social act; it both underscores the reciprocal nature of the punishment for a murderer and emphasises that that punishment is in the hands of human society. Beyond

a way that renders these dispensations exclusive to the cases of rotzeach and go'eil hadam (shenei ketuvin haba'in ke'echad) - that is, only in the case of murder can anyone kill the criminal in any way possible. Note, though, that the Bavli (bSan 72b) derives this same pair of dispensations for the case of the ba bemachteret: since the perpetrator is assumed to pose a threat to the life of the householder, he may be killed by anyone in any way possible. Note also that, while the law permitting the slaying of this perpetrator is exceptional (in that the slaying is before the fact and preventive rather than after the fact and punitive) and non-judicial, the gemara introduces (and rejects) possible presuppositions based on seeing this law from the perspective of judicial capital procedure (for example, perhaps one cannot kill the perpetrator on Shabbat (bSan 72b); note also the application to this case of the principle that a person liable for the death penalty does not incur a monetary penalty (bSan 72a) and the question of whether a hatra' $a$ is required in order for someone to kill a pursuer to save the intended victim). This same sugya includes the hatra' $a$ from Gen. 9:6 in two sources (the second is essentially the same as tSan 11:4, while the first is unique to this passage), the first relating to the pursuer and the second relating to murder to be punished by the court, but both of which the Bavli interprets (at least initially) as relating to the case of a pursuer. The first of these sources includes, after the quotation of Gen. 9:6, what the verse is being cited to suggest: 'save this person's blood with this person's blood'. The verse is being understood thus: 'He who intends to spill the blood of a human being, on account of a human being his blood shall be spilt.' (See Rashi on bSan 72b, s.v. vehatora amra, and see LXX for a similar understanding of ba'adam (see n. 68, above); in both cases adam is understood to refer to the victim, rather than to the murderer or the one who will slay the murderer, as in the interpretations cited in n. 33, above.) Gen. 9:6, then, is presented as the mandate for a social, non-judicial response to the would-be murderer. This same source, though, provides the hatra' $a$ and the onesh for the judicial response to the crime of murder (see n. 78, above, and accompanying text). Essentially, then, murder is an act that demands the response of society's members, whether to prevent its commission or to punish its committer. Anyone can kill the murderer in any way, whether to keep him from killing or to respond to his having killed. Formalised for the judiciary, this translates into the court imposing the mita of hereg for murder - but the laws of bekhol adam and bekhol mita emphasise that the original mandate to human society to respond to murder is not superceded; it is merely implemented through the court, when that is possible. See the following paragraph for hereg as the court's implementation of human society's response to murder.

${ }^{85}$ In bBava Metzia $31 \mathrm{~b}$, the only other crime punishable by hereg is also said to have the dispensation of killing in any way possible. Based on a midrashic reading of Deut. 13:16, the gemara says that the inhabitants of ir hanidachat, for whom the Torah mandates death by sword, can be killed in any way available if it is not possible to kill them by sword. (Tannaitic sources mention other crimes for which, if you cannot impose the designated mode of capital punishment, you impose an alternative mode of execution. See Mekhilta deRashbi, pp. 172-173 (for one who strikes father or mother, for one who steals and sells a person, and for one who curses father or mother) and Sifre Devarim 94, p. 155 for the law of ir hanidachat. These sources, though, seem to suggest only that beit din can impose a different form of mitat beit din, not that the criminals in these cases can be killed in any way at all, which is what bSan 45b and bBava Metzia $31 \mathrm{~b}$ say for the cases of murder and ir hanidachat. See Shemesh, 'Elu hen haNeheragin', and see Tosafot on bMak 2a, s.v. kol hazomemin maqdimin le'ota mita.) See 'Crimes and Punishments, Part I', n. 15, on the killing of the inhabitants of ir hanidachat in the Torah as a social, rather than judicial, response to their apostasy. While rabbinic texts see the killing of these people in a judicial context, perhaps we should see ir hanidachat as well as murder as cases where rabbinic sources regulate the social response through judicial procedure, but as retaining in rabbinic sources the underlying notion of a social response - first, in that the designated mitat beit din is hereg and, second, in the fact that formal execution is not the only way that the violator can be killed. 
the uniqueness of the mode of execution, the most plausible understanding of a difficult passage in the Bavli suggests that the execution of the murderer is unique in another way: he is killed, upon conviction by the court, by the go'eil hadam. ${ }^{86}$ Once again, the court incorporates rather than supercedes the

${ }^{86}$ Deut. 19:12 says explicitly that the intentional murderer is to be handed over by the elders to the go'eil hadam to be put to death. This verse is quoted in a baraita in bMak 10b in the context of the procedure for bringing murderers to trial after their initial flight to the city of refuge; see also mMak 2:6 and Sifre beMidbar, p. 220. None of these rabbinic sources specifies who it is that performs the execution if the murderer is found guilty, though, nor is the Bavli more explicit. Num. 35:19 says that the go'eil hadam kills the intentional murderer, but this is not described as occurring in the context of judicial procedure. Num. 35:27 permits (or directs-see mMak 2:7 and the discussion in bMak 12a) the go'eil hadam to kill the unintentional murderer who has left the city of refuge after being sent there by the community that determined the murder to have been unintentional. The difficult passage in bSan $45 \mathrm{~b}$ cites Num. 35:19 to teach that, if there is no go'eil hadam, the court appoints a go'eil hadam. The question disputed by classical commentators is - what is the function of the go'eil hadam referred to here? Rashi (s.v. vego'eil hadam) takes this to refer to the go'eil hadam's killing the unintentional murderer who leaves the city of refuge. This interpretation is difficult both because the gemara cites Num. 35:19, referring to intentional murder, rather than Num. 35:27, referring to the unintentional murderer who has left the city of refuge, and also because it is hard to reconcile this passage, if interpreted this way, with the baraita in bMak 12a which discusses whether Num. 35:27 commands or permits the go'eil hadam to kill the unintentional murderer and whether individuals other than the go'eil hadam are permitted or forbidden to kill this person. The most plausible alternative understanding of the passage in bSan $45 \mathrm{~b}$ is that it is the go'eil hadam's job to kill the murderer upon conviction in court; if there is no go 'eil hadam, the court must appoint someone to stand in his stead and to kill the murderer as a surrogate go'eil hadam. This understanding is adopted by the Yad Rama (p. 89) and the author of Chidushei haRan; the latter, though, foregrounds another role of the go'eil hadam or his surrogate: to prosecute the murderer in court (see bSan $37 \mathrm{~b}$ and n. 71, above). Nachmanides (on Sefer haMitzvot, in his mitzvat asei 13) also highlights the go'eil hadam's role in the judicial process, but somewhat differently: it is the go'eil hadam's job to seek vengeance by pursuing the murderer and bringing him to trial; but, then, it is only if the court is unable to execute the murderer that the go'eil hadam does so. The go'eil hadam, then, stands behind the judicial process but does not actually participate in it. Maimonides' position is difficult to pin down. In Hilkhot Rotzeach 1:2, he says that the go'eil hadam kills the convicted murderer; if he doesn't want to or is unable to, or if there is no go'eil hadam, then the court executes the murderer by sword. (Note that Maimonides does not describe this as the court appointing a surrogate go'eil, and note also the repetition here of 'by sword' when this was already stated as the designated mode of execution for murder in 1:1. Does this imply that Maimonides thinks that the go'eil hadam, if willing and able to kill the murderer, does so in any way he sees fit - that is, that the go'eil hadam does not perform a judicial execution, but rather has the murderer handed over to him by the court - and that there is a judicial execution only in the absence of a go'eil hadam?) On the other hand, see Hilkhot Sanhedrin 13:1 and 14:8; the first explicitly mentions the witnesses as executing the murderer. (Perhaps, though, we ought to take this in the context of the suggestion in the parenthetical comment above: Maimonides sees the murderer as either handed over to the go'eil hadamin to be killed or executed formally by the court; in the latter case, Maimonides takes the execution to be carried out by the witnesses, as he holds all judicial executions to be - see 'Crimes and Punishments, Part I', n. 41. If this is so, then Maimonides' position is different from, say, the Yad Rama or Chidushei haRan: they have the go'eil hadam executing the convicted murderer with a surrogate go'eil hadam appointed by the court in his absence, while Maimonides has either the go'eil hadam killing the convicted murderer outside of standard capital procedure or the court executing him under standard procedure for the execution of criminals.) As noted, the simplest and most plausible understanding of the passage in bSan $45 \mathrm{~b}$ is that the convicted murderer is killed by the go'eil hadam and that, if this is not possible, the court appoints a surrogate go'eil hadam to kill the murderer. Thus, uniquely for murder, the social dimension of the crime and of the response to that crime is foregrounded even when the crime is brought under the purview of the judicial system. 
social response to murder. While it is the court's job to regulate this response, to acquit the inadvertent homicide and to convict the intentional murderer, the judicial response to murder, at the end of the process, reverts back to the primordial notion that 'he who spills the blood of a human being, by a human being shall his blood shall be spilt' (Gen. 9:6). ${ }^{87}$

While hereg is an irregular procedure for the beit din, rabbinic sources see hereg as the standard way that communal bodies other than beit din perform executions: the non-Jewish government ${ }^{88}$ and the Jewish king execute by sword, ${ }^{89}$ and, of course, execution by sword is the punishment mandated for violation of noachide law within the dominant approach that I have char-

87 Two other indications that murder, unlike other crimes within the sinaitic system, is seen as retaining a natural law character merit consideration. First, the murderer who was unaware of the illegality of his act (omeir mutar) is not considered to have acted beshogeig; he is in the category of qarov lemeizid (bMak 7b). See n. 35, above, on the idea that ignorance of the law is not an excuse for violations of noachide law. While the murderer who acts in ignorance of the law is not punishable in beit din, the fact that his act is not treated as shogeig suggests that knowledge of the prohibition is not the fundamental ingredient in rendering an act of murder criminal. And, by being excluded from obtaining sanctuary in the city of refuge, this murderer is vulnerable to being killed by the go'eil hadam (see Maimonides, Hilkhot Rotzeach 6:4 and 10).

Second, in its discussion of which crimes one ought to give up one's life rather than violate (bSan 74a), the Bavli bases its inclusion in this category of murder on sevara - reason-rather than on biblical texts, from which the other laws in this category are derived. (In fact, sexual offences are derived from a biblical text that juxtaposes adultery and murder, Deut. 22:26, though the derivation of murder itself is not scriptural.) The implication is that, even in the hard case of 'one should be killed and not transgress', we can conclude the wrongness of murder based on reason; a biblical text is not necessary to teach this law. (I am indebted to David Silber for pointing out the relevance of this passage to the argument presented here on the nature of murder. See also J. D. Bleich, 'Judaism and Natural Law', Jewish Law Annual 7 (1988), 6-42.)

It is noteworthy, though, that Rashi's understanding of this passage locates the sevara squarely within a positivist framework. Rashi understands the question "who is to say that your blood is redder than his [i.e. that the blood of the person who is told to kill or be killed is redder than the blood of the proposed victim] ...' as cancelling out the consideration of vechai bahem (Lev. 18:5) - understood as the injunction to preserve life even if means violating a commandment, rather than relinquish life in order to avoid violating a commandment. That is, for Rashi, we analyse the prohibition of murder no differently than any other prohibition: fundamentally, we must not disobey 'the word of the king', but the principle of vechai bahem tells us that, generally, God prefers that we preserve life even if it means violating a commandment. In the case of murder, though, life would not be preserved if the commandment is violated; there is loss of life whether the person transgresses or does not transgress, and who is to say that the life of the person who must decide whether or not to kill is more valuable to God than the other person's life? Since, then, we cannot apply the consideration of vechai bahem to allow transgression of God's command, we are left bound by that command not to kill. While the gemara, then, seems to see this choice as based on reason, Rashi sees it as deriving from a clear-cut prohibition; the sevara, according to Rashi, only serves to show why we cannot, in this case, apply the usually overriding divine imperative of vechai bahem. See the discussion of Tanna deVei Menashe's prohibition of cross-breeding, above, for another example of Rashi interpreting from a positivist perspective a statement that I have suggested reflects a natural law conception.

88 mSan 7:3.

89 Both tSan 9:10 and ySan 7:1/24b comment, in relation to the four modes of judicial execution (mSan 7:1), on the more limited mandate to the government (generally taken to refer to the Jewish king, as opposed to the non-Jewish monarch of mSan 7:3) to execute only by sword; this comment does not appear in the Bavli. See G. Blidstein, 'On Political Structures-Four Medieval Comments', The Jewish Journal of Sociology 22 (1980), 47-58, for some medieval discussions of the power of the king, and see 'Crimes and Punishments, Part I', n. 5. 
acterised as a system of law basic to the functioning of human society. ${ }^{90}$ The unique use of hereg by the beit din in the case of murder, then, marks murder as a crime that is unique within the sinaitic system. While sinaitic law forbids murder and stipulates the sanction of death for the murderer, murder retains its essence as a crime against human society to be addressed by human society.

\section{Summary and Further Questions}

The fundamental hypothesis of this study is that rabbinic choices of punishment reflect rabbinic conceptions of jurisprudence. In Part I, I focused on the sanction of cheneq, the default mode of execution assigned in rabbinic sources to violations of sinaitic law, and suggested that the nature of cheneq reflects the rabbinic understanding of the nature of sinaitic law and its violation. In Part II, I have looked beyond the example of sinaitic law in order both to test the hypothesis that punishment in rabbinic sources can be understood to reflect jurisprudence and to sharpen the characterisation that I have offered of the rabbinic understanding of sinaitic law.

First, I looked at noachide law, an alternative system of law envisioned in rabbinic sources, focusing on the two versions of noachide law presented in the Bavli. I analysed the nature of these two versions of noachide law in contrast to the nature of sinaitic law, and suggested that, here too, we can see the designated punishment within each version of noachide law as reflecting the particular conception of the nature of law that characterises each of the versions.

Second, I looked at the Torah's prohibition of achoto and suggested that, within rabbinic sources, it is seen as the quintessential sinaitic law-both in that its prohibitedness and punishability derive exclusively from legislation, rather than from an essential quality of the prohibited act, and in its place as the source of fundamental principles of sinaitic jurisprudence - and, as such, sharpens the distinction made between rabbinic conceptions of sinaitic and noachide law.

Finally, I looked at the law of murder and suggested that anomalies within the rabbinic treatment of this crime reflect the fact that murder, uniquely, is

90 See the comment of the Or Sameach on Maimonides, Hilkhot Melakhim 3:10 (the power of the king to execute a murderer based on the testimony of one witness); he sees both the power of the king and the mandate of the go'eil hadam as deriving from the same need for social order (tiqun hamedina) that underlies noachide law. Note that Maimonides includes noachide law in Hilkhot Melakhim. See Rakover, 'Jewish Law', for the notion that din melekh is a form of the noachide law/natural law obligation to preserve justice, and see A. Enker, 'Aspects of Interaction Between the Torah Law, the King's Law, and the Noachide Law in Jewish Criminal Law', Cardozo Law Review 12 (1991), 1137-56, on the relationship between the supplementary powers of the court and king to preserve social welfare and the noachide obligation of dinin (note, however, that the supplementary powers of the court are not, in fact, limited to crimes relating to social welfare - see bSan 46a). The notion that dinin has its proper place within society (see, for example, the Mishne Tora passage discussed in n. 24, above), though it specifically mandates the institution of courts to regulate and formalise the social response to criminal behaviour, is parallel to the notion that murder is properly responded to by the go'eil hadam or other members of human society, though the court is empowered to regulate and implement the social response to murder (see nn. 84-86, above). 
seen as a wrong done in the world, the criminal nature of which does not derive from the prohibiting command of God. An exception to the rabbinic conception of law and its violation, murder is also, uniquely, assigned the punishment of hereg, a punishment which reflects not only the distinctiveness of murder but also the particular nature of this act as a crime against human society, rather than solely the violation of a divine command. Thus, like the two versions of noachide law, the crime of murder offers a test case for the hypothesis that choices of punishment within rabbinic sources reflect rabbinic conceptions of the nature of law.

The ideas developed in this study about punishment and jurisprudence suggest a number of intriguing questions for further inquiry, some of which relate to directions in contemporary scholarship. First, the look at punishment here has been limited to mitot beit din. It would be worthwhile to look at other punishments discussed in rabbinic texts, such as the sanction of malqot (flagellation), ${ }^{91}$ to see what ideas - and, especially, what jurisprudential ideasmight be reflected by them. And it would be interesting to extend this inquiry to legal principles relating to punishment, such as the principle that one cannot incur both a monetary penalty and capital or corporal punishment, ${ }^{92}$ and to analyse the underlying judisprudential assumptions of such principles, as well.

Second, the jurisprudence described here in relation to mitot beit din is the rabbinic conception of sinaitic law, and it is based in the notion of command as embodied (explicitly or through exegesis) in Scripture. I did not, though, touch on rabbinic conceptions of rabbinic law (not to mention rabbinic conceptions of rabbinic interpretation of sinaitic law); it would be worthwhile to do so in the context of the conception suggested here of sinaitic law. In addition, it would be intriguing to try to locate the jurisprudential model described here in relation to other developments in the rabbinic conception of law, such as the development of a complex scriptural exegesis presented as the source of much biblical law and other evidence of a text-based, as opposed to conventional or customary, approach to law. ${ }^{93}$

91 See, for example, A. Shemesh's study of malqot, The Punishment of Flagellation in the Tannaitic Sources (in Hebrew), PhD dissertation, Bar Ilan University (Ramat Gan, 1994); while focusing on tanaitic sources, the study includes significant discussion of Bavli material.

92 On the development of these two principles within the Bavli, see Z. Dor, 'The Punishments of Monetary Compensation and Flagellation in Talmudic Literature' (in Hebrew), Sinai 54 (1974), 120-39, and B. Lifshitz, 'Does a Man Not Receive Both the Death Penalty and Pay Damages? (On the Question of the Origin of the Rule "Kam leh Miderabah Mineh")' (in Hebrew), Shenaton Ha-Mishpat Ha-Ivri 8 (1981), 153-246.

${ }^{93}$ For some conjectures about the turn to the biblical text as the source of law and about the development of scriptural exegesis to substantiate legal rulings, see J. Neusner, A Life of Rabban Yohanan ben Zakkai (Leiden, 1962), especially pp. 82-82; A. Schremer, “"They Did Not Read in the Sealed Book": Qumran Halakhic Revolution and the Emergence of Torah Study in Second Temple Judaism', in D. Goodblat, A. Pinnick and D. R. Schwartz, eds., Historical Perspectives: From the Hasmoneans to Bar Kokhba in Light of the Dead Sea Scrolls (Leiden, 2001), pp. 105-26; and A. Shemesh, The Punishment of Flagellation; see also the classic essays by I. Heineman, 'On the Development of Technical Terms for Scriptural Exegesis, I, d.r.sh' (in Hebrew), Leshoneinu 14 (1946), 182-89, and E. E. Urbach, 'The Derasha as a Basis of the Halakha and the Problem of the Soferim' (in Hebrew), Tarbiz 27 (1958), 166-82. Shemesh points to a shift in the definition of 
Third, it would be worthwhile to contrast the conception of law described here with alternate conceptions of law in non-rabbinic Jewish circles, ${ }^{94}$ such as the conception of law in Jubilees or in Qumran texts. ${ }^{95}$ And, along with this third avenue of inquiry, it would be intriguing to consider how the rabbinic conception of law and punishment might relate to other rabbinic ideas and how alternative conceptions in non-rabbinic circles might relate to fundamental ideas in those communities. One particularly intriguing investigation would be to explore the possible relationship between a natural law conception and a deterministic world view, ${ }^{96}$ on the one hand, and between a positivist conception of law and the idea of free will, on the other.

Besides the particular interpretation offered here of mitot beit din and rabbinic jurisprudence, the foregoing discussion has bearing on some key questions relating to how we look at the Bavli as a redacted text. As noted in the introductory section of Part I of this study, while many of the ideas presented here about punishment and jurisprudence would seem to be shared by rabbinic sources other than the Bavli, the interpretation suggested here of the relationship between punishment and jurisprudence should be seen as reflecting these ideas particularly as they are developed within the Bavli. In the section on noachide law, in particular, I highlighted how distinctive the Bavli's presentation of the material in fact is. The analysis of noachide law, as well as that of other topics discussed here concerning punishment and jurisprudence, might contribute to our understanding of how the Bavli recasts traditional material to reflect particular conceptual frameworks. ${ }^{97}$

Further, the discussion of the sugya on noachide law raises questions about the relationship between sugyot in the Bavli and their broader contexts. ${ }^{98}$ The

prohibitions $\left(l a^{\prime}\right.$ vin $)$ as marked by a negative formulation in the biblical text, rather than by the simple fact that the law is something that one ought not do, and attributes this shift to R. Aqiva, in contrast to R. Yishma'el, who holds the older and less text-based view; see pp. 9-12 of the introduction and, in more detail, chapter three. This correlates with the difference in the oneshsource for murder cited in the two Mekhiltas; see n. 78, above. Mekhilta deRabbi Yishma'el cites a pre-sinaitic source, the same verse that serves as the source for punishment within noachide law (see text at $\mathrm{n} .78$ for a characterisation of this verse), while Mekhilta deRashbi cites a sinaitic sanction with a standard legal formulation. It is interesting, also, that it is to R. Aqiva that the Bavli attributes the idea that there is no prohibition of achoto for a noachide (see n. 52, above). Perhaps we should see R. Aqiva as representing the idea that sinaitic law is radically different from noachide law: the latter deriving from a non-legislative natural law idea, with the former deriving exclusively from legislation as embodied in the biblical text (explicitly or as midrashically interpreted).

94 Whether or not these are contemporaneous.

95 See, for example, D. Schwartz, 'Law and Truth: On Qumran-Sadducean and Rabbinic Views of Law', in The Dead Sea Scrolls: Forty Years of Research, ed. D. Dimant and U. Rappaport (Leiden and Jerusalem, 1992), 229-40, and C. Werman, 'The Torah and the Te 'uda on the Tablets' (in Hebrew), Tarbiz 68 (1999), 473-92.

96 See Weinreb, Natural Law, pp. 37-38, for a statement of this issue as it relates to Stoic thought.

97 For a recent review of scholarship on the Bavli's redactors' recasting of traditional sources, see J. Rubenstein, Talmudic Stories: Narrative Art, Composition, and Culture (Baltimore, 1999), especially pp. 15-21.

98 See J. Rubenstein, Narrative Art, pp. 11-15, for a discussion of the contexts of Bavli aggadot; Rubenstein emphasises the need to look at the literary, as well as cultural, contexts of talmudic stories. 
sugya on noachide law seems at first glance to be a digression from the main focus of its broad context: judicial procedure and punishment. The analysis offered above, though, might suggest that the sugya on noachide law-coming as it does after the talmudic description of capital procedure and punishment and at the beginning of its listing of crimes punishable by the different forms of judicial execution - underscores a central point about the broader talmudic discussion of crime and punishment and helps us read that broader discussion as reflecting one among a variety of possible jurisprudential models. Seeing the sugya on noachide law as central, rather than tangential, to the larger subject of bSanhedrin/Makkot might, in turn, lead us to wonder whether the enumeration of seven noachide laws in the middle of bSan is related to the famous sugya at the end of bMak (23b-24a) in which sinaitic law is said to consist of 613 commandments and which includes, as the number of core commandments is successively reduced, a reflection on the essence of that body of law. If so, then this final sugya, along with the sugya on noachide law, might invite us to re-look at bSan/Mak not only as a discussion of laws about judicial procedure and punishment but as an essay on rabbinic jurisprudence. And, more generally, such an investigation might raise new questions and offer some insight into the degree that we might see the editing of a talmudic tractate as being guided, in part, by broad thematic concerns. 